Proceedings

\title{
Plant Secondary Metabolites - A Necessary Resource for Both Man and Papilionid Butterflies Across West Bengal, India ${ }^{\dagger}$
}

\author{
Panchali Sengupta
}

Citation: Sengupta, P. Plant Secondary Metabolites-a necessary resource for both man and papilionid butterflies across West Bengal, India, in Proceedings of the 1st International Electronic Conference on Entomology, 1-15 July 2021, MDPI: Basel, Switzerland, doi:10.3390/IECE-10492

Published: 1 July 2021

Publisher's Note: MDPI stays neutral with regard to jurisdictional claims in published maps and institutional affiliations.

Copyright: (c) 2021 by the authors. Submitted for possible open access publication under the terms and conditions of the Creative Commons Attribution (CC BY) license (http://creativecommons.org/licenses /by/4.0/).

\author{
Department of Zoology, West Bengal State University, Berunanpukaria, Malikapur, Barasat, West Bengal, \\ India \\ * Correspondence: panchali17sg@gmail.com \\ + Presented at the 1st International Electronic Conference on Entomology (IECE 2021), 1-15 July 2021; \\ Available online: https://iece.sciforum.net/.
}

\begin{abstract}
Chemical factors or plant secondary metabolites (PSM) contributes towards larval host plant choice among butterflies. Significantly, such PSM are the basis of ethnomedicinal plants as recognised by traditional healers since time immemorial. A total of 27 papilionid butterflies utilizing 26 species of medicinal plants as their ovipositing substrate were observed. Graphium cloanthus, $G$, sarpedon, G, eurypylus (PI values: 3.873) were polyphagous species. On the contrary, G. antiphates, G. nomius, Atrophaneura polyeuctes, A. aidenous, Troides helena, (PI: 1.000) were strictly monophagous. The medicinal utilization values $\left(\mathrm{U}_{\mathrm{v}}\right)$ of such plant species was recognised. Aristolochia indica $\left(\mathrm{U}_{\mathrm{v}}=0.474\right)$ and Citrus medica $\left(\mathrm{U}_{\mathrm{v}}=0.44\right)$ appeared to be the most popular medicinal plant among the proponents of ethnomedicine.
\end{abstract}

Keywords: butterflies; ethnomedicine; plant secondary metabolites; polyphagy; medicinal utilization values

\section{Introduction:}

Indigenous knowledge is known to generate an inexhaustible information database for its exponents. Such has been the contribution of medicinal plants towards the well being of its practitioners since centuries. The popularity associated with such plants have been mentioned even in Charaka Samhita, Susruta Samhita, Rig-Veda, Astanga Hridaya, Ramayana and Mahabharata [1,2]. WHO has reported the utilization of traditional medicines amongst $80 \%$ populace from developing nations [3]. Plant secondary metabolites (PSM) or more specifically alkaloids, terpenoids, flavonoids, glycosides, coumarins, saponins and tannins constitutes the basis of such formulations as used by folklore therapists. Their immense popularity thereby creates an urgent demand for the conservation and judicious utilization of these plant resources.

Interestingly, butterflies have developed an innate skill to recognise and utilize such plants as reliable ovipositing substrate. Several species have devised strategies to overcome the defensive substances (PSM) characteristics of plant taxa [4-6]. Although being totally dependant on floral resources as adult, the demand for tender foliage in their larval stage cannot be overlooked. Butterflies thus exhibit a "botanical instinct" in selecting the most perfect host plant suitable for egg deposition [7]. As larvae butterflies are known to exhibit host plant specificity by being monophagous, polyphagous or oligophagous. Significantly such chemical constituents (PSM) are critically important in establishing an intrinsic butterfly-host plant relationship.

Thus the present study would attempt to explain the significance of PSM in the life of butterflies as well as an essential element of ethnomedicine. The determination of medicinal utilization value ( $\left.U_{v s}\right)$ for each studied plant species would also be helpful in deciphering their extent of therapeutic benefits. Additionally the degree of polyphagy 
would be investigated with an attempt to generate an idea of larval food plant specificity of butterflies.

\section{Material and Methods:}

Study Design

The entire study was conducted between June 2019 to May 2020 across tribal dominated districts of West Bengal (East and West Midnapore, Darjeeling, Jalpaiguri, Purulia and Bankura), India. The initial phase of study involved documentation of papilionid butterflies utilizing medicinal plants as their larval resource. Several instances of larvae feeding on plants belonging to one or more plant order or family or genera or species were observed for determining their monophagous / polyphagous nature.

Identification of butterfly larval host plants up to species was conducted from specially designed quadrats laid for such purpose. On field identification of plants was done based on earlier reports in most instances along with direct observation of larvae during such survey. Such observations were later confirmed from published literature [8-10]. Additionally plant species were also identified from previous publications [11-17].

In the final phase of investigation, detailed ethno-medicinal survey was undertaken to emphasise the therapeutic benefits of such plants. This involved an informal dialogue designed to gather information from knowledgeable and experienced populace including ojhas, kabiraaj and vaidyas. Such people were initially interviewed based on specially designed questions prepared for such purpose, followed by group discussion and informal meeting whenever required. Information thus obtained were documented in datasheet without any modification.

\section{Data Analysis:}

Polyphagy as evident among butterfly species was determined using polyphagy in$\operatorname{dex}(\mathrm{PI})$ where $\mathrm{PI}=(\mathrm{A} \times \mathrm{B})^{1 / 2}$; where $\mathrm{A}=$ number of genera of host plants, and $\mathrm{B}=$ taxonomic diversity of the hosts $(1=$ one plant species; $2=$ one plant genus; $3=$ one plant family; $4=$ one plant order; $5=$ two or more plant orders) [18].

Estimation of medicinal values $\left(\mathrm{U}_{\mathrm{vs}}\right)$ of each species " $\mathrm{s}$ " was done based on the following:[19-20]. The formulae used was $U_{v s}=\Sigma U_{s} / n_{s}$ where $U_{s}$ in the number of medicinal uses of the species "s" as mentioned by informant and $\mathrm{n}_{\mathrm{s}}$ was the number of informants who provided the information.

\section{Results:}

A total of 27 papilionid species utilizing 26 species of medicinal botanicals as their larval food resource was identified across districts of West Bengal, India. Five plant families i.e. Rutaceae (38.46\%), Lauraceae (19.23\%), Magnoliaceae and Annonaceae (15.38\%) and Aristolochiaceae (11.54\%) were reported as larval food resource of butterflies (Table $1)$.

Table 1. List of papilionid species along with their ovipositing plants and polyphagy index.

\begin{tabular}{|c|c|c|c|}
\hline $\begin{array}{l}\text { Sr. } \\
\text { No. }\end{array}$ & Papilionid larval species & Ovipositing plant species & $\begin{array}{c}\text { Polyphagy Index } \\
\text { (PI) }\end{array}$ \\
\hline 1 & Graphium cloanthus Westwood & $\begin{array}{c}\text { Family: Magnoliaceae } \\
\text { Michelia champaca Linn. } \\
\text { Michelia doltsopa Buch.-Ham. ex } \\
\text { DC. } \\
\text { Family: Lauraceae } \\
\text { Cinnamomum camphora (L.) J. Presl. } \\
\text { Persea odoratissima (Nees) Kosterm. }\end{array}$ & 3.873 \\
\hline 2 & Graphium sarpedon (Linnaeus) & $\begin{array}{c}\text { Family: Annonaceae } \\
\text { Polyalthia longifolia Hk. f. \& T. }\end{array}$ & 3.873 \\
\hline
\end{tabular}




\begin{tabular}{|c|c|c|c|}
\hline & & $\begin{array}{l}\text { Family: Lauraceae } \\
\text { Cinnamomum camphora (L.) J. Presl } \\
\text { Persea odoratissima (Nees) Kosterm }\end{array}$ & \\
\hline 3 & Graphium eurypylus (Linnaeus) & $\begin{array}{c}\text { Family: Annonaceae } \\
\text { Annona reticulata L } \\
\text { Polyalthia longifolia } \mathrm{Hk} . \mathrm{f} . \& \mathrm{~T} . \\
\text { Family: Lauraceae } \\
\text { Cinnamomum camphora } \text { (L.) J. Presl }\end{array}$ & 3.873 \\
\hline 4 & Graphium chironides (Honrath) & $\begin{array}{c}\text { Family: Magnoliaceae } \\
\text { Magnolia pterocarpa Roxb. }\end{array}$ & 1.000 \\
\hline 5 & Graphium doson (C.\& R. Felder) & $\begin{array}{l}\text { Family: Magnoliaceae } \\
\text { Michelia champaca Linn } \\
\text { Magnolia grandiflora L } \\
\text { Family: Annonaceae } \\
\text { Polyalthia longifolia Hk. f. \& T. }\end{array}$ & 3.464 \\
\hline 6 & Graphium agamemnon (Linnaeus) & $\begin{array}{l}\text { Family: Magnoliaceae } \\
\text { Michelia champaca Linn } \\
\text { Family: Annonaceae } \\
\text { Annona squamosa Linn } \\
\text { Annona reticulata L } \\
\text { Polyalthia longifolia } \mathrm{Hk} \text {. f. \& T }\end{array}$ & 3.464 \\
\hline 7 & Graphium antiphates (Cramer) & $\begin{array}{c}\text { Family: Annonaceae } \\
\text { Uvaria lurida Hk. f. \& T. }\end{array}$ & 1.000 \\
\hline 8 & Graphium nomius (Esper) & $\begin{array}{c}\text { Family: Annonaceae } \\
\text { Polyalthia longifolia Hk. f. \& T }\end{array}$ & 1.000 \\
\hline 9 & Chilasa epycides (Hewitson) & $\begin{array}{c}\text { Family: Lauraceae } \\
\text { Cinnamomum camphora (L.) J. Presl } \\
\text { Persea odoratissima (Nees) Kosterm. }\end{array}$ & 2.449 \\
\hline 10 & Chilasa agestor (Gray) & $\begin{array}{c}\text { Family: Lauraceae } \\
\text { Cinnamomum tamala Nees. } \\
\text { Persea odoratissima (Nees) Kosterm. }\end{array}$ & 2.449 \\
\hline 11 & Chilasa clytia (Linnaeus) & $\begin{array}{c}\text { Family: Lauraceae } \\
\text { Litsæa glutinosa (Lour.)C.B.Rob. } \\
\text { Cinnamomum camphora (L.) J. Presl } \\
\text { Cinnamomum tamala Nees. }\end{array}$ & 2.449 \\
\hline 12 & Chilasa slateri (Hewitson) & $\begin{array}{c}\text { Family: Lauraceae } \\
\text { Litsæa glutinosa (Lour.)C.B.Rob. } \\
\text { Litsæa polyantha Juss. } \\
\text { Cinnamomum camphora (L.) J. Presl }\end{array}$ & 2.449 \\
\hline 13 & Papilio helenus Linnaeus & $\begin{array}{c}\text { Family: Rutaceae } \\
\text { Glycosmis pentaphylla Correa. } \\
\text { Toddalia asiatica Lamk. }\end{array}$ & 2.449 \\
\hline 14 & Papilio polytes Linnaeus & $\begin{array}{c}\text { Family: Rutaceae } \\
\text { Glycosmis pentaphylla Correa. } \\
\text { Citrus grandis (L.) Osbeck } \\
\text { Citrus limon (L.) Burm. f. } \\
\text { Aegle marmelos Correa. } \\
\text { Citrus medica Linn. } \\
\text { Murraya koenigii Spreng. }\end{array}$ & 3.464 \\
\hline 15 & Papilio castor Westwood & $\begin{array}{c}\text { Family: Rutaceae } \\
\text { Glycosmis pentaphylla Correa. } \\
\text { Toddalia asiatica Lamk. }\end{array}$ & 2.449 \\
\hline 16 & Papilio memnon Linnaeus & $\begin{array}{c}\text { Family: Rutaceae } \\
\text { Citrus grandis (L.) Osbeck } \\
\text { Citrus limon (L.) Burm. f. } \\
\text { Citrus medica Linn. }\end{array}$ & 1.414 \\
\hline
\end{tabular}




\begin{tabular}{|c|c|c|c|}
\hline 17 & Papilio polymnestor Cramer & $\begin{array}{c}\text { Family: Rutaceae } \\
\text { Glycosmis pentaphylla Correa. } \\
\text { Citrus grandis (L.) Osbeck } \\
\text { Citrus aurantium Linn. }\end{array}$ & 2.449 \\
\hline 18 & Papilio demoleus Linnaeus & $\begin{array}{c}\text { Family: Rutaceae } \\
\text { Glycosmis pentaphylla Correa. } \\
\text { Citrus grandis (L.) Osbeck } \\
\text { Aegle marmelos Correa. } \\
\text { Citrus medica Linn. }\end{array}$ & 3.000 \\
\hline 19 & Papilio krishna Moore & $\begin{array}{c}\text { Family: Rutaceae } \\
\text { Citrus medica Linn. } \\
\text { Zanthoxylum acanthopodium DC. }\end{array}$ & 2.449 \\
\hline 20 & Papilio paris Linnaeus & $\begin{array}{c}\text { Family: Rutaceae } \\
\text { Citrus medica Linn. } \\
\text { Toddalia asiatica Lamk. }\end{array}$ & 2.449 \\
\hline 21 & Papilio polyctor Boisduval & $\begin{array}{c}\text { Family: Rutaceae } \\
\text { Zanthoxylum acanthopodium DC. } \\
\text { Clausena excavata Burm. }\end{array}$ & 2.449 \\
\hline 22 & $\begin{array}{c}\text { Atrophaneura polyeuctes } \\
\text { (Doubleday) }\end{array}$ & $\begin{array}{c}\text { Family: Aristolochiaceae } \\
\text { Aristolochia tagala Cham. \& Schlect. }\end{array}$ & 1.000 \\
\hline 23 & $\begin{array}{c}\text { Atrophaneura aristolochiae } \\
\text { (Fabricius) }\end{array}$ & $\begin{array}{c}\text { Family: Aristolochiaceae } \\
\text { Aristolochia tagala Cham. \& Schlect. } \\
\text { Aristolochia indica L. }\end{array}$ & 1.414 \\
\hline 24 & Atrophaneura hector (Linnaeus) & $\begin{array}{c}\text { Family: Aristolochiaceae } \\
\text { Aristolochia tagala Cham. \& Schlect. } \\
\text { Aristolochia saccata Wall. }\end{array}$ & 1.414 \\
\hline 25 & Atrophaneura varuna (White) & $\begin{array}{c}\text { Family: Aristolochiaceae } \\
\text { Aristolochia tagala Cham. \& Schlect. } \\
\text { Aristolochia saccata Wall. }\end{array}$ & 1.414 \\
\hline 26 & Atrophaneura aidoneus (Doubleday) & $\begin{array}{l}\text { Family: Aristolochiaceae } \\
\text { Aristolochia saccata Wall. }\end{array}$ & 1.000 \\
\hline 27 & Troides helena (Linnaeus) & $\begin{array}{c}\text { Family: Aristolochiaceae } \\
\text { Aristolochia tagala Cham. \& Schlect. }\end{array}$ & 1.000 \\
\hline
\end{tabular}

G. cloanthus, G, sarpedon, $G$, eurypylus (PI values: 3.873 ) were widely popular polyphagous species. Interesting, observation on G. doson, G. agamemnon and P. polytes ( $\mathrm{PI}=3.464$ ) were noted (Table 1). While G. doson and G. agamemnon were recognised for utilizing plants belonging to single plant order, $P$. polytes utilized multiple species belonging to a single family (Rutaceae). On the contrary, G. antiphates, G. nomius, A. polyeuctes, A. aidenous, T. helena, (PI: 1.000) were strictly monophagous (Table 1).Other notable observation on the medicinal utilization values ( $\left.U_{v s}\right)$ of the papilionid larval plant species revealed some interesting findings (Table 2). A. indica $\left(\mathrm{U}_{\mathrm{v}}=0.474\right)$ and C. medica $\left(\mathrm{U}_{\mathrm{v}}=0.44\right)$ appeared to be the most popular among folklore therapists. However M. champaca (0.39), C. camphora (0.37), G. pentaphylla (0.37), C. aurantinum (0.380) and A. tagala (0.36) with $\mathrm{U}_{\mathrm{v}} \geq$ 0.35 were also popular among traditional healthcare practitioners (Table 2).

Table 2. List of medicinal plant species along with their pharmacological benefits and medicinal utilization values.

\begin{tabular}{|c|c|c|c|}
\hline $\begin{array}{l}\text { Sr. } \\
\text { no. }\end{array}$ & Plant species & Pharmacological benefit & $\begin{array}{l}\text { Utilization } \\
\text { values }\left(U_{v}\right)\end{array}$ \\
\hline 1 & $\begin{array}{l}\text { Family: Magnoliaceae } \\
\text { Michelia champaca Linn. }\end{array}$ & $\begin{array}{c}\text { Anti-inflammatory, analgesic, nerve } \\
\text { soothing effect, treatment of skin } \\
\text { diorders, gout. Effective in } \\
\text { aromatherapy }\end{array}$ & 0.39 \\
\hline
\end{tabular}




\begin{tabular}{|c|c|c|c|}
\hline 2 & Michelia doltsopa Buch.-Ham. ex DC. & $\begin{array}{l}\text { Treatment of dyspepsia, gonorrhea, } \\
\text { stomach disorders, tonsillitis, fever. } \\
\text { Also useful as deworming agent }\end{array}$ & 0.31 \\
\hline 3 & Magnolia pterocarpa Roxb. & $\begin{array}{l}\text { Effective in treatment of fever and } \\
\text { cough }\end{array}$ & 0.30 \\
\hline 4 & Magnolia grandiflora $\mathrm{L}$ & $\begin{array}{c}\text { Antiinflammatory, diaphoretic, } \\
\text { stimulant, prevention against cold, } \\
\text { headache and stomach ache }\end{array}$ & 0.32 \\
\hline 5 & $\begin{array}{l}\text { Family: Lauraceae } \\
\text { Cinnamomum camphora (L.) J. Presl }\end{array}$ & $\begin{array}{l}\text { Camphor used to treat high fever, } \\
\text { measles, delirium, whooping cough, } \\
\text { melancholia, bronchitis, uterine pain, } \\
\text { asthma, gonorrhoea, rheumatism, } \\
\text { headache and influenza }\end{array}$ & 0.37 \\
\hline 6 & Cinnamomum tamala Nees. & $\begin{array}{l}\text { Beneficial for the treatment of itch, } \\
\text { diarrhoea, colic, rheumatism, fever, } \\
\text { anaemia, nausea and vomiting }\end{array}$ & 0.30 \\
\hline 7 & Persea odoratissima (Nees) Kosterm. & $\begin{array}{l}\text { Anti-inflammatory, antiseptic, antiviral, } \\
\text { anti-allergic, effective againest } \\
\text { snakebite, burn wounds, improves } \\
\text { cardiac output, reduces congestive } \\
\text { heart failure and cardiac arrhythmia }\end{array}$ & 0.30 \\
\hline 8 & $\begin{array}{c}\text { Family: Annonaceae } \\
\text { Polyalthia longifolia Hk. f. \& T. }\end{array}$ & $\begin{array}{c}\text { Treatment of fever, skin disease, } \\
\text { diabetes, hypertension, constipation. } \\
\text { Known for its anti- } \\
\text { inflammatory ,anticancer, antimicrobial, } \\
\text { antiulcer activity }\end{array}$ & 0.32 \\
\hline 9 & Annona reticulata $\mathrm{L}$ & $\begin{array}{l}\text { Treatment of epilepsy, dysentery, } \\
\text { cardiac problem, worm infection, } \\
\text { constipation, haemorrhage, } \\
\text { antibacterial infection, dysuria, fever, } \\
\text { hyperthyroidism and ulcer, Possess } \\
\text { ntitumor, antifertility and abortifacient } \\
\text { properties, }\end{array}$ & 0.32 \\
\hline 10 & Annona squamosa Linn & $\begin{array}{l}\text { Beneficial for cardiac disease, } \\
\text { hyperthroidism and cancer, Used as a } \\
\text { purgative and applied on ulcer and } \\
\text { wounds. Possess antitumor, } \\
\text { antidiabetic, antimicrobial, } \\
\text { antihyperlipidemic and } \\
\text { hepatoprotective activity. }\end{array}$ & 0.30 \\
\hline 11 & Uvaria lurida Hk. f. \& T. & $\begin{array}{c}\text { Treatment of inflammatory disease, } \\
\text { rheumatism, acute allergic reaction, } \\
\text { inflammatory liver disease and swollen } \\
\text { joints. }\end{array}$ & 0.19 \\
\hline 12 & Litsæa glutinosa (Lour.)C.B.Rob. & $\begin{array}{l}\text { Treatment of furnacle, traumatic injury, } \\
\text { reducing swelling and soreness. }\end{array}$ & 0.16 \\
\hline 13 & Litsæa polyantha Juss. & $\begin{array}{c}\text { Treatment of fractures and dislocation. } \\
\text { Cures gonorrhea, skin disease, boil, } \\
\text { diarrohea, pain and bruises }\end{array}$ & 0.24 \\
\hline 14 & $\begin{array}{c}\text { Family: Rutaceae } \\
\text { Glycosmis pentaphylla Correa. }\end{array}$ & $\begin{array}{l}\text { Treatment of bilious complaints, cough, } \\
\text { jaundice, fever, inflammation, } \\
\text { rheumatism, anaemia, vermifuge. Also } \\
\text { known for its hepatoprotective, } \\
\text { antiinflammatory, antimicrobial, } \\
\text { antiulceritive, chemoprotective, }\end{array}$ & 0.37 \\
\hline
\end{tabular}




\begin{tabular}{|c|c|c|c|}
\hline & & $\begin{array}{l}\text { antipyretic, antitumor, wound healing } \\
\text { and insecticidal activity. }\end{array}$ & \\
\hline 15 & Toddalia asiatica Lamk. & $\begin{array}{l}\text { Treatment of sprains, convulsions, } \\
\text { intercostal neuralgia, cough, malaria, } \\
\text { garstral dysentery, snakebite and } \\
\text { furnucle. Possess antiviral, antimalarial } \\
\text { and anticancer effect. }\end{array}$ & 0.27 \\
\hline 16 & Murraya koenigii Spreng. & $\begin{array}{l}\text { A number of pharmacological activities } \\
\text { such as anti-tumor, anti-oxidative, anti- } \\
\text { mutagenic and anti-inflammatory have } \\
\text { been reported }\end{array}$ & 0.27 \\
\hline 17 & Aegle marmelos Correa. & $\begin{array}{c}\text { Known to lower blood glucose levels. } \\
\text { Plant also possesses antifungal } \\
\text { properties }\end{array}$ & 0.22 \\
\hline 18 & Zanthoxylum acanthopodium & $\begin{array}{c}\text { Treatment of fever, gastric problems, } \\
\text { liver complaints and dental problems. } \\
\text { Possess antihelminthic and carminative } \\
\text { properties. }\end{array}$ & 0.18 \\
\hline 19 & Clausena excavata Burm. & $\begin{array}{l}\text { Treatment of nausea, constipation and } \\
\text { cardio-vascular disorders, Also possess } \\
\text { anti-inflammatory and spasmolytic } \\
\text { properties. }\end{array}$ & 0.29 \\
\hline 20 & Citrus medica Linn. & $\begin{array}{l}\text { Acts as astringent and to treat blood } \\
\text { disorders. Also possess analgesic, } \\
\text { antidiabetic, antitumor, antimicrobial } \\
\text { and hypocholesterolamic properties. }\end{array}$ & 0.44 \\
\hline 21 & Citrus grandis (L.) Osbeck & $\begin{array}{l}\text { Possess antioxidant, antimicrobial and } \\
\text { antidiabetic properties. Effective as a } \\
\text { cardiac stimulant and stomach tonic. }\end{array}$ & 0.32 \\
\hline 22 & Citrus limon (L.) Burm. f. & $\begin{array}{c}\text { Provides relief from cough and cold, } \\
\text { fever, soreness, rheumatism, kidney } \\
\text { disorders, cardiac diseases, anaemia } \\
\text { and digestive problems }\end{array}$ & 0.23 \\
\hline 23 & Citrus aurantium Linn. & $\begin{array}{c}\text { Effective against dyspepsia, asthma, } \\
\text { obesity, sleeplessness }\end{array}$ & 0.38 \\
\hline 24 & $\begin{array}{l}\text { Family: Aristolochiaceae } \\
\text { Aristolochia tagala Cham. \& Schlect. }\end{array}$ & $\begin{array}{c}\text { Effective against stomachache, } \\
\text { snakebite ,dental problems and } \\
\text { rheumatism }\end{array}$ & 0.36 \\
\hline 25 & Aristolochia saccata Wall. & $\begin{array}{l}\text { Provides relief from fever, diarrohea } \\
\text { and dysentry }\end{array}$ & 0.23 \\
\hline 26 & Aristolochia indica L. & $\begin{array}{l}\text { Effective against cholera, fever, bowel } \\
\text { problems, ulcers, leprosy, and skin } \\
\text { diseases. Also being employed as an } \\
\text { abortifacient and antineoplastic }\end{array}$ & 0.47 \\
\hline
\end{tabular}

\section{Discussion:}

Investigation on papilioninae has been conducted with the aim to explore the wide repertoire of medicinal botanicals satisfying their larval food resource requirements. Such strategies designed to effectively utilize these plants thereby enlightens the significance of these plants in life of butterflies. Additionally phytochemical and pharmacological properties of such plants have dominated most of the primary treatment imparted in healthcare system, Significantly, Rutaceae, Lauraceae, Annonaceae, Magnoliaceae and Aristolochiaceae known for their secondary metabolites constituents are beneficial not only for papilioninae but also for the folklore therapists. 
Terpenoids (viz. $\alpha$-pinene, $\beta$-pinene, limonene, myrcene, linalool, terpinolene) are abundantly associated with Citrus [21-22]. Besides hesperidin and neohesperidin found both in C.limon and C. grandis, naringenin, naringin and rutin are predominant flavonoids isolated from C. grandis [23]. Z. acanthopodium is recognised for its unique terpenoids (ie. linalool, phytol, 1-8 cineole, farnesol, $\beta$-caryophyllene) [24]. Toddalia, also possesses alkaloids viz. toddalin, toddalidimerine, dihydroviridine along with terpenoids [25]. Alkaloids such as aeglin, aegelenine, dictamine, fragrine, [26] along with few terpenoids (pcymene, limonene and $\alpha$-phellandrene) [26-27] are essential ingredients of A. marmelos. Koenine, koenigine, girininbine, koenimbine, isomahanine, bismahanine are reported from M. koenigii [28]. Besides terpenoids (eudesmol, pinene, camphene, limonene, caryophyllene), some alkaloids viz. magnocurarine, magnoflorine, auonaine, michelarbine, liriodenine, salicifol, tubocurarine are found in Magnolia [29]. Additionally Polyalthia are known for its two clerodane type of diterpenes[ 30]. Besides, oxygenated mono and sesquiterpenes, mono and sesquiterpene hydrocarbons are found among Persea [31]. Tetradecanal, tridecanal, myristic acid from L. polyantha bark [32] and 9,12 octadecadienoic acid, hexadecanoic acid, stigmasic-5-en-3ol from L. glutinosa [33] also reveal some interesting findings. Terpenoids from C. camphora include cineol, limonene, $\alpha$-humulene, $\beta$-cardinine, D-camphor, $\alpha$-terpineol, linalool, $\gamma$-terpinene, $\alpha$-pinene, $\beta$-pinene and eugenol [34-36]. $C$. tamala bark has also reported the occurrence of following terpenoids viz. phellandrene, eugenol, linalool, $\alpha$-pinene, p-cymene, $\beta$-pinene and limonene [37]. Both alkaloids (ie. phenolic and nonphenolic alkaloids, aporphine alkaloids: annonamine, crystalline alkaloid: muricine and muricinine, roemerine, corydine, norisocorydine, samoquasine A) and terpenoids (linalool, carvone, acetogenin: squamocin A, squamocin B are also abundant in Annona [38-39]. 8 types of aristolactam type alkaloid and 7 arristolochic acid derivatives are quite significant in A. tagala [40] However, terpenoids viz. pinene, pinocarvone, transpinocarvol, are the major components of $A$. indica [41].

A cocktail of terpenes ( $\alpha$-pinene, sabinene, $\beta$-myrcene, limonene, $\beta$ - phellandrene, ocimene, germacrene-A, bisabolene, germacrene- $\mathrm{B}$, oxygenated sesquiterpenes and 3-hydroxy-2-butyrate) released by fourth instar larva along with aliphatic acids and their esters in fifth instar are worth mentioning. Graphini (G. doson and G.antiphates) are known to possess aliphatic acids and their esters in both the final instar stages [42]. Papilionii exudates reveal presence of terpenoids in fourth instar followed by aliphatic acids in final instar stage [43-45]. In contrast troidinii's osmeterial secretion contains aristolochic acids (AAs) [46-48]. Caterpillars of P.polytes, P. demoleus, P. paris were reported to experience a change in body colour and pattern during transition from penultimate to ultimate stage. Such an unique ability to mimic brown and white bird droppings to small green snakes [49] in fifth instar could be attributed to an alteration in their osmeterial chemistry [50]. Therefore such variability in the osmeterial composition among Papilionini and Graphinii provide a clue towards plesiomorphic trait in them [48]. On the contrary troidinii upon sequestering AAs are know to generate a primary line of defence against birds and vertebrates [51].

Greater utilization values $\left(\mathrm{U}_{\mathrm{v}}\right)$ of $A$. indica and C. medica in this study highlighted their probable benefits for the proponents of traditional medicine. Alkaloids, widely recognised for their immense therapeutic benefits viz. antitumor, anti-inflammatory, antimalarial and antiviral contribute towards several modern day drug formulation [52-54]. Equally beneficial and enormously popular, plant terpenoids are considered to be a proven remedy against fever, bronchitis, asthma, microbial, cancer, fungal and viral infection $[55,37,56,22,29]$.

Episodes of G. cloanthus, G. sarpedon, G. eurupylus, G. doson and G agamemnon feeding from more than one plant family describing their polyphagous nature is probably aimed at utilizing a wide spectrum of secondary metabolites Papilio demoleus and P.polytes 
feeding on multiple species of rutaceous plants also denote their polyphagous nature Thus polyphagous species are known to employ a wide repertoire of phytochemicals probably as stimulus for oviposition. In contrast strict monophagy as evident among G.antiphates, G. nomius, A. polyeuctus, A. aidoneus, T. helenus signified their restricted feeding preference. Interestingly, such single family association among papilioninae viz.papilionii with Rutaceae and troidini with Aristolochiaceae are noteworthy [57-58].

\section{Conclusion:}

Ethnobotany serves as a tool for preparation of several novel herbal formulations by utilization of the indigenous knowledge of ethnic people. Custom associated with the use of wild population of medicinal plants has lead to the creation of enormous pressure leading to uncontrolled exploitation of forest resource for commercial purposes. Significantly such mismanagement of floral resources could negatively effect the larval population of butterflies dependant on those specific medicinal plants. Thereby proper conservation and management of medicinal plants becomes an important issue in the present scenario. Thus the present study could provide a platform for designing of futuristic policies regarding natural resource management keeping in mind the demand of traditional practitioners. Additionally such a system should also ensure the availability of larval food resource of butterflies in turn ensuring their survival.

Acknowlegments:The author is highly grateful to Prof. Narayan Ghorai for his valuable suggestion and cooperation during the study. The constant support and encouragement of the faculty members of the Department of Zoology, West Bengal State University is also acknowledged.

Conflict of interest:The author declare no conflict of interest

\section{References}

1. Sinhababu, A.; Banerjee, A. Documentation of some ethno-medicinal plants of family Lamiaceae in Bankura district, West Bengal, India. International Research Journal of Biological Sciences 2013, 2(6), 63-65.

2. Rao, R.R. Medicinal plants of India: Diversity, conservation and bioprospection-concerns and strategies for $21^{\text {st }}$ centaury. In: Medicinal plants of India:Conservation and sustainable use, (eds) Tripathi, S.K.; Upadhyaya, K.; Hedge, N. Today and tomorrow's Printers and publishers: N. Delhi, India, 2019,pp.1-38

3. Ghosh A. Ethnomedicinal plants used in West Rarrh region of West Bengal Natural Product Radiance 2008, 7(5), 461-465.

4. Theis N.; Lerdau, M. The evolution of function in plant secondary metabolites International Journal of Plant Sciences 2003, 164, S93-S102.

5. Wink, M. Evolution of secondary metabolites from an ecological and molecular phylogenetic perspective. Phytochemistry 2003, 64(1), 3-19.

6. Ali, J. G.; Agrawal, A. A. Specialist versus generalist insect herbivores and plant defence. Trends in Plant Science 2012, 17(5), 293302.

7. Ramana, S. V. Biodiversity and conservation of butterflies in the Eastern Ghats. The Ecoscan 2010, P4(1), 59-67.

8. Haribal, M. The Butterflies of Sikkim Himalaya and Their Natural History. Sikkim, Sikkim Natural Conservation Foundation, Gangtok, 1992, pp. 217.

9. Igarashi, S.; Fukuda, H. The life histories of Asian butterflies. Vol. 1. Tokai University Press, Tokyo, 1997, pp. 550.

10. Kehimkar, I. The Book of Indian Butterflies. Bombay Natural History Society, Oxford University Press, New Delhi, 2008, pp. $\mathrm{xvi}+497$.

11. Cowan, A.; Cowan, J. M. The trees of Northern Bengal including Shrubs, Woody Climbers, Bamboos, Palms and Tree Ferns, Naaz Offset Press, Delhi, 1979, pp. 178.

12. Rai, P. C.; Das, A. P. Analysis of the Flora of Neora Valley National Park in Darjeeling District of West Bengal, India. In: Perspective of Plant Biodiversity, (ed). Das, A. P. Dehradun: Bhishen Singh Mahendra Pal Singh. 2002, pp. 135-150.

13. Rai, P. C.; Das, A. P. Ethnobotanical significance of the flora of Neora Valley National Park in the district of Darjeeling, West Bengal (India). Bulletin of the Botanical Survey of India 2004, 46(1-4), 337-355.

14. Polunin, O.; Stainton, A. Flowers of the Himalaya. Seventh Impression. Oxford University Press, New Delhi, 2005, pp. xxx+580.

15. Maity, D.; Maiti, G.G. The Wild Flowers of Kanchenjunga Biosphere Reserve, Sikkim, Naya Udyog, Kolkata, 2007, pp.174.

16. Das, A. P.; Bhujel, R. B.; Lama, D. Plant Resources in the Protected Areas and Proposed Corridors of Darjeeling, India. In: Biodiversity Conservation in the Kangchenjunga Landscape, (eds). Chettri, N.; Shakya, B.; Sharma, E. Hill Side Press (P.) Ltd., Kathmandu, 2008. pp. 57-79.

17. Das, A. P.; Samanta, A. K.; Ghosh, C. A checklist of angiospermic climbers of Darjiling and Sikkim parts of Eastern Himalaya including Terai and Duars. Pleione 2010, 4(2), 185-206. 
18. García-Barros, E.; T. Fartmann. Butterfly oviposition: sites, behaviour and modes. In: Ecology of Butterflies in Europe. (Eds.), Settele, J.; Shreeve, T.; Konvička, M.; Van Dyck. H. Cambridge University Press, Cambridge, 2009, pp. 29-42

19. Phillips, O.; Gentry, A.H. The useful plants of Tambopata, Peru: I.Statistical hypotheses tests with a new quantitative techniques. Economic Botany 1993a, 47, 15-32

20. Phillips, O.; Gentry, A.H. The useful plants of Tambopata, Peru: II. Additional hypotheses testing in quantitative ethnobotany Economic Botany 1993b, 47, 33-43.

21. Baik, Seok, J.; Kim, S-S.; Lee, J-A.; Oh, T-H.; Kim, J-Y.; Lee, N.H.; Hyun, C-G.Chemical composition and biological activities of essential oils extracted from Korean endemic Citrus species. J. Microbiol. Biotechnol. 2008, 18(1), 74-79.

22. Akono, P. N.; Mbida, J.A.M.; Dongmo, P.M.J.; Tonga, C.; Tchamga, L.A.D.; Mounbain, F.; Magne, G.T.; Mache, P.N.; Kekeunou, S. Chemical composition and insecticidal activity of essential oils of Cinnamomum zeylanicum, Citrus grandis, Citrus medica and Citrus sinensis leaves from Cameroon on Anopheles gambiae Giles, 1902. Journal of Entomology and Zoology Studies 2016, 4(6), 17-23.

23. Ali, Md. Y.; Rumpa, Nur-E. N.; Paul, S.; Hossen, Md. S.;Tanvir, E.M.;Hossan,T; Saha, M.; Alam, N.; Karim, N.; Khalil, Md. I.; Gan, S. H. Antioxidant potential, subacute toxicity and beneficiary effects of methanolic extract of pomelo (Citrus grandis L. Osbeck) in long evan rats. Journal of Toxicology 2019, 12

24. Yonzone, R.; Rai, S. Zanthoxylum acanthopodium DC. (Rutaceae)-a favourable ethnomedicinal fruit for the local inhabitants of Darjeeling Himalaya of West Bengal, India. Journal of Complementary Medicine \& Alternative Healthcare 2016, 1(1), 555554.

25. Rajkumar, M.; Chandra, R.H.; Asres, K.; Veeresham, C. Toddalia asiatica (Linn.) Lam.-A comprehensive Review. Pharmacognosy reviews 2008, 2(4),386-397

26. Manandhar, M. D.; Shoeb, A.; Kapil, R. S.; Popli, S.P. New alkaloids from Aegle marmelos. Phytochemistry 1978, 17, 1814-1815

27. Yadav N. P.; Chanotia, C. S. Phytochemical and pharmacological profile of leaves of Aegle marmelos Linn. The Pharmaceutical Reviews 2009, 144-159

28. Tachibana, Y; Kikuzaki, H.; Lajis, N. H.; Nakatani, N. Comparison of antioxidative properties of carbazole alkaloids from Murraya koenigii leaves. J. Agric Food Chemistry 2003, 51, 6461-6467

29. Mir, A.H.; Jeri, L.; Upadhaya, K.; Bhat, N.A.; Borah, R.; Choudhury, H.; Kumar, Y. Diversity, Bioprospection and commercial importance of Indian Magnolias. Plants for human survival and Medicine 2019, 227-250.

30. Katkar, K. V.; Suthar, A. C.; Chauhan, Y. S. The chemistry, pharmacologic and therapeutic applications of Polyalthia longifolia. Pharmacognosy Reviews 2010, 4(7), 62-68.

31. Pant, P.; Khulbe, K.; Pant, C. C Essential oil composition and antioxidant, antibacterial activity of leaf extract of Persea odoratissima (Nees). European Journal of Biomedical and pharmaceutical Sciences 2018, 5(4), 527-536.

32. Choudhury, S. N.; Ghosh, A.C.; Choudhury, M.; Leclercq, P.A. Essential oils of Litsea (Roxb.) Pers. A new report from India. J. Essent. Oil Res. 1997, 9(6), 635-639.

33. Arunodaya, H.S.; Krishna, V.; Shashikumar, R.; Girish kumar, K. Antibacterial and antioxidant activities of stem bark essential oil constituents of Litsea glutinosa C. B. Rob. Int J. Pharm Pharm Sci. 2016, 8(12), 258-264.

34. Chelliah, A. D. Biological Activity prediction of an ethno medicinal plant Cinnamomum camphora through bio-informatics. Ethnobotanical Leaflets 2008,12, 181-190.

35. Ho, C.-L.; Wang Eugene, I-C.; Su, Y-C. Essential oil compositions and bioactivities of the various parts of Cinnamomum camphora Sieb var., linaloolifera Fujuta 2009, 31(2),77-95.

36. Joshi, S. C.; Padalia, R. C.; Bisht, D. S.; Mathela, C. S. Terpenoid diversity in the leaf essential oils of Himalayan Lauraceae species. Chemistry and Biodiversity,2009, 6(9), 1364-1373.

37. Shah, M.; Panchal, M.; Ethnopharmacological properties of Cinnamomum tamala-A Review. International Journal of Pharmaceutical Sciences: Review and Research 2010, 5(3), 141-144.

38. Pandey, N.; Barve, D. Phytochemical and pharmacological review on Annona squamosa Linn. International Journal of Research in Pharmaceutical and Biomedical Sciences 2011, 2(4), 1404-1412

39. Zaman, K.; Pathak, K. Pharmacognostical and phytochemical studies on the leaf and stem bark of Annona reticulata Linn. Journal of Pharmacognosy and Phytochemistry 2012, 1(5), 1-8

40. Liu, R.; Zhang, H-C. Chemical constituents from Aristolochia tagala and their chemotaxonomic significance. Biochemical Systematics and Ecology 2020, 90, 104037.

41. Grover, J. K.; Yadav, S.; Vats, V. Medicinal plants of India with antidiabetic potential. Journal of Ethnopharmacology 2002, 81, 81100.

42. Honda, K. Osmeterial secretion of papilionid larvae in the genera Luehdorfia, Graphium and Atrophaneura (Lepidoptera). Insect Biochem. 1980a, 10, 583-588.

43. Honda, K. Volatile constituents of larval osmeterial secretions in Papilio protenor demetrius. J. Insect Physio, 1980b, 26, 39-45

44. Honda, K. Larval osmeterial secretions of the swallowtail (Papilio). J. Chem Ecol 1981, 7, 1089-1113

45. Burger, B.V.; Munro, Z.; Roth, M., Spies, H.S.C.; Truter, V.; Geertsema, H.; Habick, A. Constituents of osmeterial secretions of pre-final instar of citrus swallowtail butterfly, Papilio demodocus (Esper) (Lepidoptera: Papilionidae) Journal of Chemical Ecology 1985, 11, 1093-1113.

46. Nishida, R.; Fukami, H. Ecological adaptation of an Aristolochiaceae feeding swallowtail butterfly, Atrophaneura alcinous, to aristolochic acids. J. Chem. Ecol. 1989, 15, 2549-2563

47. Nishida, R. Sequestration of plant secondary compounds by butterflies and moths. Chemoecology 1995, 5/6, 127-138 
48. Sime, K. R.; Feeny, P. P.; Haribal, M. M. Sequestration of aristolochic acids by the pipevine swallowtail, Battus philenor (L.): evidence and ecological implications. Chemoecology 2000, 10,169-178.

49. Igarashi, S. Papilionidae and their early stages 1979, Kodansha, Tokyo, Japan,

50. Ômura, H.; Honda, K.; Feeny, P. From terpenoids to aliphatic acids: further evidence for late-instar switch in osmeterial defense as a characteristic trait of swallowtail butterflies in the tribe Papilionini Journal of Chemical Ecology 2006, 12, 1999-2012

51. Young, A.M. Notes on the life cycle and natural history of Parides arcas myoletes (Papilionidae) in costarican premontane wet forest, Psyche 1973, 80, 1-21.

52. Roy, A. A review on the alkaloids an important therapeutic compound from plants. International Journal of Plant Biotechnology 2017, 3(2) 1-9

53. Chakravarthy, K. B.; Guptha S.; Tode, K. Functional beta-cell regeneration in the islets of pancreas in alloxan-induced diabetic rats by (-)-epicatechin. Life Science1982, 31, 2693-2697.

54. Muthumani, P.; Ramseshu, V. K.; Meera, R.; Devi, P. Phytochemical investigation and anti-microbial and enzyme inhibition activity of Murraya koenigii (Linn). International Journal of Pharmaceutical and Biological Archives 2010, 1, 345-349.

55. Paria, N. Medicinal plant resources of South West Bengal, Kolkata. Directorate of Forests, Govt. of West Bengal, 2005, pp.xi +198

56. Brahmkshatriya, P.P.; Brahmkshatriya, P. S. Terpenes: Chemistry, Biological role and therapeutic applications, In: Natural Products, (eds), Ramawat, K.; Merillon, J. M.. Springer, Berlin, Heidelberg. 2013, pp. 2665-2691

57. Smetacek, P. On the anomalous altitudinal distribution of West Himalayan Troidini and Papilionini (Papilionidae). Journal of the Lepidopterists' Society, 2011, 65(2), 126-132.

58. Condamine, F. L.; Sperling, F.A,H.; Wahlberg, N.; Rasplus, J.Y.; Kergoat, G.J.What causes latitudinal gradients in species diversity? Evolutionary processes and ecological constaints on swallowtail biodiversity. Ecology Letters 2012, 15, $267-277$. 